$\begin{array}{ll}\text { Volume }: 06 \\ \text { Nomor } & : 03 \\ \text { Bulan } & : \text { September } 2020 \\ \text { Tahun } & : 2020 \\ \text { http } & : / / \text { ejurnal.pps.ung.ac.id/index.php/Aksara }\end{array}$

\title{
Pengaruh Keadilan Organisasi Terhadap Komitmen Organisasi Dengan Kepuasan Kerja Sebagai Variabel Mediasi
}

\author{
Karolus Wulla Rato, Abdul Rahmat \\ e-mail: karlosrato@yahoo.co.id, abdulrahmat@ung.ac.id
}

Received: 08 Juli 2020; Revised: 21 Agustus 2020; Accepted: 28 Agustus 2020

DOI: http://dx.doi.org/10.37905/aksara.6.2.97-102.2020

\begin{abstract}
Abstrak
Penelitian ini bertujuan untuk menganalisis pengaruh keadilan organisasi terhadap komitmen organisasi dengan kepuasan kerja sebagai variabel mediasi. Terdapat tiga hipotesis yang dibangun dalam penelitian ini, yaitu: 1) keadilan organisasi berpengaruh secara positif terhadap komitmen organisasi, 2) Keadilan organisasi berpengaruh positif terhadap kepuasan kerja, 3) kepuasan kerja memediasi pengaruh keadilan organisasi terhadap komitmen organisasi. Metode pengumpulan data melalui penyebaran kuesioner kepada responden secara langsung. Responden dalam penelitian ini adalah karyawan PT. Borneo Melintan Buana Yogyakarta. Jumlah kuesioner yang dibagikan sebanyak 98 buah. Teknik uji terpakai menggunakan uji validitas, dan uji reliabilitas. Pengujian hipotesis pertama dan kedua menggunakan uji regresi linear sederhana. Pengujian hipotesis ketiga menggunkana path analysis dalam perhitungannya untuk mengetahui adanya pengaruh mediasi. Hasil penelitian menunjukan bahwa keadilan organisasi berpengaruh positif dan signifikan komitmen organisasi dan kepuasan kerja memediasi pengaruh keadilan organisasi terhadap komitmen organisasi
\end{abstract}

\section{Kata Kunci: Keadilan Organisasi, Komitmen Organisasi, Kepuasan Kerja}

\section{PENDAHULUAN}

Penelitian tentang keadilan organisasi menjadi topik yang menarik sebagai bahan riset sejak lebih dari 25 tahun yang lalu (Colquitt, 2001). Kepuasan kerja dan komitmen organisasi dihubungkan dengan beraneka ragam hasil dari suatu pekerjaan, seperti keadilan organisasi dan prestasi kerja (Crow, Matthew Lee, Bae, Joo dan Jin, 2012; Nurmaladita dan Warsindah 2015). Beberapa penelitian sebelumnya (Fulford., 2005; Leen dan Wei, 2015) menemukan bahwa faktor yang dapat mempengaruhi komitmen organisasi ditempat kerja adalah adanya keadilan organisasi. Secara garis besar para pekerja atau karyawan menilai kembali keadilan organisasi yaitu keadilan interaksional,keadilan prosedural dan keadilan distibusi.

Beberapa penelitian sebelumnya (Crow et al., 2012) ; (Niazi et al., 2014). Dari serangkai penelitian tersebut menunjukkan bahwa kepuasan kerja sangat berperan terhadap keadilan organisasi dan komitmen organisasi. Menurut Kreitner dan Kinicki (2013), terdapat lima faktor yang mempengaruhi kepuasan kerja yaitu : pemenuhan kebutuhan (need fulfiment), perbedaan (disrepancies), pencapaian nilai (value attainment), keadilan (equity) dan komponen genetik (genetic components). Dengan 
terpenuhinya kelima faktor tersebut, karyawan akan termotivasi untuk berkomitmen di tempat kerja.

Selain ditemukan adanya pengaruh keadilan organisasi terhadap komitmen organisasi, adapun faktor lain yang juga memberikan pengaruh kedua variabel tersebut, yaitu kepuasan kerja. Keadilan organisasi berpengaruh terhadap komitmen organisasi yang memediasi adalah kepuasan kerja (Fulford 2005; Spagnool dan Cantona, 2012). Penelitian yang sama yang dilakukan oleh (Niazi et al., 2014) memasukan vairiabel mediasi yaitu kepuasan kerja. Kedua variabel keadilan organisasi terhadap komitmen organisasi menunjukan kepuasan kerja memediasi.

Penelitian lain (Crow et al., 2012) memasukan kepuasan kerja sebagai mediasi di dalam penelitian untuk menguji pengaruh keadilan organisasi terhadap komitmen polisi. Penelitian tersebut menyatakan bahwa kepuasan kerja sebagai faktor yang memediasi pengaruh keadilan organisasi terhadap komitmen polisi. Adapun kepuasan kerja sebagai psikologi yang turut mempengaruhi hubungan antara keadilan organisasi terhadap komitmen organisasi.

Dalam penelitian ini, peneliti ingin menguji sejauh mana Pengaruh Keadilan Organisasi Terhadap Komitmen Organisasi dengan Kepuasan Kerja sebagai Variabel Mediasi di PT. Borneo Melintang Buana. Acuan dasar penelitian ini adalah pada penelitian yang dilakukan Niazi et al., 2014) dan (Crow et al., 2012) (, dengan mengubah dan memperluas unit analisis yaitu PT. Borneo Melintang Buana.

\section{METODE}

Penelitian ini dilakukan dengan menggunakan pendekatan kuantitatif dan alat pengkuran berupa kuesioner. Penelitian ini mengambil populasi yaitu seluruh karyawan yang bekerja PT. Borneo Melintang Buana tahun 2017 berjumlah 364 karyawan. Subjek penelitian adalah orang yang diminta memberikan keterangan tentang suatu fakta atau pendapat. Sebagai subjek penelitaian ini adalah para karyawan di PT. Borneo Melintang Buana tahun 2017.

Metode pengambilan data dalam penelitian ini bersumber dari data primer dan sekunder. Metode pengumpulan data di dalam penelitian ini menggunakan SelfAdministered Surveys yaitu data di kumpulkan dengan menyebarkan kuesioner kepada responden secara langsung (Cooper dan Schindler, 2014).

Subjek penelitian adalah orang yang diminta memberikan keterangan tentang suatu fakta atau pendapat. Sebagai subjek penelitian ini adalah para karyawan di PT. Borneo Melintang Buana tahun 2017. Populasi penelitian ini berjumlah 234 karyawan. Sampel 98

\section{HASIL DAN PEMBAHASAN}

Dalam bab IV ini penulis sajikan analisis terhadap data yang telah penulis peroleh selama penelitian di PT. Borneo Melitang Buana. Analisis data yang penulis lakukan ini pada dasarnya dapat dikelompokkan menjadi dua bagian yaitu bagian pertama, merupakan analisis data yang sifatnya deskriptif. Sedangkan bagia kedua, merupakan analisis data yang sifatnya inferensi atau pengujian hipotesis. Dalam bab ini penyusun juga menyampaikan pembahasan dalam kaitan dengan hasil analisis data tersebut. 
Tabel 4.1 Karakteristik Responden

\begin{tabular}{|c|c|c|c|}
\hline \multicolumn{2}{|c|}{ Karakteristik } & Jumlah & Persentasi \\
\hline \multirow{3}{*}{ Jenis Kelamin } & Laki-laki & 71 & $72,4 \%$ \\
\cline { 2 - 4 } & Perempuan & 27 & $27,6 \%$ \\
\cline { 2 - 4 } & Total & 98 & $100 \%$ \\
\cline { 2 - 4 } & $20-30$ & 28 & $28,6 \%$ \\
\cline { 2 - 4 } & $31-40$ & 50 & $51,0 \%$ \\
\cline { 2 - 4 } & $41-50$ & 20 & $20,4 \%$ \\
\cline { 2 - 4 } & $51-60$ & 2 & $2,0 \%$ \\
\hline \multirow{6}{*}{ Pendidikan } & Total & 98 & $100 \%$ \\
\cline { 2 - 4 } & SMP & 3 & $3,1 \%$ \\
\cline { 2 - 4 } & SMA & 89 & $90,8 \%$ \\
\cline { 2 - 4 } & S1 & 98 & $100 \%$ \\
\hline \multirow{7}{*}{ Masa Kerja } & Total & 37 & $37,8 \%$ \\
\cline { 2 - 4 } & $1-5$ & 40 & $40,8 \%$ \\
\cline { 2 - 4 } & $6-10$ & 17 & $17,3 \%$ \\
\cline { 2 - 4 } & $11-15$ & 4 & $4,1 \%$ \\
\cline { 2 - 4 } & $16-20$ & 98 & $100 \%$ \\
\hline
\end{tabular}

Sumber: data diolah, 2017

Berdasarkan Tabel 4.1, diketahui bahwa mayoritas responden berjenis kelamin pria sebanyak 70 orang atau $71,4 \%$, dibandingkan dengan responden perempuan yang berjumlah 27 orang 27,6\%, kemudian usia diantara 31 sampai 40 tahun adalah yang terbanyak dengan 50 orang atau 51,0\%, sedangkan minoritas responden usia 51 sampai 60 tahun berjumlah 2 orang 2,0\%. Dari segi pendidikan, responden lulusan SMA mendominasi dengan 89 orang atau $90,8 \%$ sedangkan responden dengan pendidikan terakhir SMP sebanyak 2 orang 3,1\% dan responden dengan masa kerja antara 6 sampai 10 tahun adalah yang terbanyak dengan 40,8 \% . Sedangkan paling sedikit adalah responden lama kerja 16-20 tahun sebanyak 4 orang atau 4,1\%.

\section{Variabel Keadilan Organisasi}

Persepsi responden terhadap variabel keadilan organisasi dapat lihat pada Tabel 4.2 sebagai berikut:

Tabel 4.2 Persepsi Responden terhadap Variabel Keadilan Organisasi

\begin{tabular}{|c|c|c|c|}
\hline Interval & Kategori & Jumlah & Persentasi \\
\hline $1,00-1,79$ & $\begin{array}{c}\text { Sangat tidak } \\
\text { setuju }\end{array}$ & 0 & $0 \%$ \\
\hline $1,80-2,59$ & Tidak setuju & 4 & $4,1 \%$ \\
\hline $2,60-3,39$ & Netral & 27 & $27,6 \%$ \\
\hline $3,40-4,12$ & Setuju & 57 & $58,2 \%$ \\
\hline $4,20-5,00$ & $\begin{array}{l}\text { Sangat } \\
\text { setuju }\end{array}$ & 10 & $10,2 \%$ \\
\hline \multicolumn{2}{|c|}{ Total } & 98 & $100 \%$ \\
\hline
\end{tabular}

Sumber: data diolah, 2017

Berdasarkan Tabel 4.1 di atas, dapat diketahui bahwa responden cenderung mengatakan setuju dengan adanyan keadilan di perusahaan. Sebanyak 57 orang atau sebesar $57,1 \%$ karyawan setuju dengan adanya keadilan organisasi, bahkan 10 orang atau $10,2 \%$ 
karyawan sangat setuju terhadap adanya keadilan organisasi. Akan tetapi ada pula karyawan yang menyatakan Netral yaitu 27 orang atau 27,6\% dan yang menyatakan tidak setuju 4 orang dengan persentase $4,1 \%$. Oleh karena itu dapat disimpulkan bahwa keadilan organisasi di PT. Borneo Melintang Buana berada pada kategori setuju.

Untuk melihat kualitas data responden, penelitian ini melakukan uji asumsi klasik yaitu dengan uji normalitas dan multikolinearitas. Dari hasil uji normalitas diperoleh nilai signifikan di atas 0,05 disimpulkan bahwa data memiliki distribusi normal. Sedangkan uji multikolinieritas, diperolah hasil perhitungan nilai tolerance lebih dari 0,10 dan nilai Variance Inflation Factor (VIF) kurang dari 10. Hasil ini mengindikasikan bahwa tidak ada multikolinieritas antar variabel independen dalam model regresi.

\section{Variabel Komitmen Organisasi}

Persepsi responden terhadap variabel komitmen organisasi dapat dilihat pada Tabel 4.2 sebagai berikut:

Tabel 4.2. Persepsi Responden terhadap Variabel Komitmen Organisasi

\begin{tabular}{|c|c|c|c|}
\hline Interval & Kategori & Jumlah & Persentasi \\
\hline $1,00-1,79$ & $\begin{array}{c}\text { Sangat tidak } \\
\text { setuju }\end{array}$ & 0 & $0 \%$ \\
\hline $1,80-2,59$ & Tidak setuju & 0 & $0 \%$ \\
\hline $2,60-3,39$ & Netral & 41 & $41,8 \%$ \\
\hline $3,40-4,12$ & Setuju & 53 & $54,1 \%$ \\
\hline $4,20-5,00$ & Sangat setuju & 4 & $4,1 \%$ \\
\hline Total & 98 & $100 \%$ \\
\hline
\end{tabular}

Sumber: data diolah, 2017

Berdasarkan data pada Tabel 4.2 di atas, menunjukan bahwa hampir seluruh karyawan setuju terhadap komitmen organisasi. Karyawan yang menyatakan setuju terhadap komitmen organisasi sebanyak 53 orang atau sebesar 54,1\% karyawan, ada 4 orang atau $4,1 \%$ karyawan yang menyatakan sangat berkomitmen terhadap perusahaan. Namun masih ada 41 atau $41,1 \%$ orang yang menyatakan netral terhadap komitmen organisasi. Mereka berkomitmen terhadap perusahaan karena mereka mendapatkan keadilan diperusahaan.

3. Variabel Kepuasan Kerja

Persepsi responden terhadap variabel kepuasan kerja dapat dilihat pada tabel 4.3 sebagai berikut:

Persepsi Responden terhadap Variabel Kepuasan

\begin{tabular}{|c|c|c|c|}
\hline Interval & Kategori & Jumlah & Persentasi \\
\hline $1,00-1,79$ & Sangat tidak setuju & 0 & $0 \%$ \\
\hline $1,80-2,59$ & Tidak setuju & 2 & $2,0 \%$ \\
\hline $2,60-3,39$ & Netral & 40 & $40,8 \%$ \\
\hline $3,40-4,12$ & Setuju & 54 & $55,1 \%$ \\
\hline $4,20-5,00$ & Sangat setuju & 2 & $2,0 \%$ \\
\hline Total & 98 & $100 \%$ \\
\hline
\end{tabular}

Sumber: data diolah, 2017 
Berdasarkan data pada tabel 4.3 di atas, menunjukan bahwa hampir seluruh karyawan setuju dan puas terhadap pekerjaannya. Karyawan yang menyatakan setuju terhadap setuju sebanyak 54 orang atau sebesar 55,1\% karyawan, ada 2 orang atau 2,0\% karyawan yang menyatakan sangat puas terhadap perusahaan. Namun masih ada 40 atau 40,8\% orang yang menyatakan netral terhadap kepuasan kerja mereka dan 2 orang yang jelasjelas menyatakan tidak puas. Mereka puas berkerja karena lingkungan kerjanya nyaman dan rekan kerja yang menyenangkan.

1. Pengujian hipotesis $1(\mathrm{H} 1)$

Hipotesis yang pertama dalam penelitian ini adalah pengaruh positif keadilan organisasi terhadap komitmen organisasi. Teknik analisis untuk menguji hipotesis pertama menggunakan analisis regresi linear sederhana. Hasil uji hipotesis pertama yaitu: keadilan organisasi berpengaruh positif terhadap komitmen organisasi, dapat dilihat pada Tabel 4.4 sebagai berikut:

Tabel 4.4 Hasil Uji Regresi keadilan organisasi terhadap komitmen organisasi ( model 1)

\begin{tabular}{|c|c|c|c|c|c|c|}
\hline Variabel & $\begin{array}{c}\text { Sta } \\
\text { ndard } \\
\text { ized } \\
\text { Coeffi } \\
\text { cients } \\
(\beta)\end{array}$ & $\mathrm{T}$ & $\mathrm{R}$ & $\begin{array}{c}\mathrm{R} \\
\text { Square }\end{array}$ & $\mathrm{F}$ & Sig. \\
\hline $\begin{array}{c}\text { Keadialan } \\
\text { Organisasi }\end{array}$ & 0,396 & 4,220 & 0,396 & 0,156 & 17,810 & 0,000 \\
\hline
\end{tabular}

Sumber: data diolah, 2017

Berdasarkan Tabel 4.4, yang diperoleh $\mathrm{r}$ sebesar 0,156 pada hubungan antara Keadilan organisasi dengan komitmen organisasi. Nilai $r$ berkisar antara 0 sampai 1 , apabila nilai semakin mendekati 1 berarti hubungan yang terjadi semakin kuat, sebaliknya nilai semakin mendekati 0 maka hubungan yang terjadi semakin lemah. Hal ini berarti bahwa terjadi hubungan yang kuat antara keadilan organisasi dengan komitmen organisasi dapat dilihat dari $\mathrm{R}$ Square yaitu sebesar 0,156. Harga t hitung $(\beta=0,396, t=4,220$, nilai $\mathrm{p} \leq 0,05)$. Maka dapat diambil kesimpulan bahwa terdapat pengaruh positif keadilan organisasi berpengaruh secara positif dan signifikan terhadap komitmen organisasi sehingga hipotesis pertama diterima.

2. Pengujian Hipotesi 2

Hipotesis yang kedua dalam penelitian ini adalah terdapat pengaruh positif keadilan organisasi dengan kepuasan kerja. Teknik analisis untuk menguji hipotesis kedua menggunakan analisis regresi linear sederhana. Hasil yang diperoleh dari analisis regresi keadilan organisasi terhadap kepuasan kerja dapat dilihat Tabel 4.8 sebagai berikut: 
Tabel 4.5 Hasil Uji Regresi keadilan organisasi terhadap kepuasan kerja ( model II)

\begin{tabular}{|c|c|c|c|c|c|c|}
\hline $\begin{array}{c}\text { Variabe } \\
1\end{array}$ & $\begin{array}{c}\text { Standar } \\
\text { dized } \\
\text { Coefficient } \\
s(\beta)\end{array}$ & $\mathrm{T}$ & $\mathrm{R}$ & $\begin{array}{c}\mathrm{R} \\
\text { Squar } \\
\mathrm{e}\end{array}$ & $\mathrm{F}$ & $\begin{array}{c}\text { Sig } \\
\cdot\end{array}$ \\
\hline $\begin{array}{l}\text { Keadialan } \\
\text { Organisasi }\end{array}$ & 0,631 & 4,554 & 0,698 & 0,487 & 91,279 & 0,000 \\
\hline
\end{tabular}

Sumber: data diolah, 2017

Berdasarkan Tabel 4.5, diperoleh $r$ sebesar 0,698 pada hubungan antara keadilan organisasi dengan kepuasan kerja. Nilai $r$ berkisar antara 0 sampai 1, apabila nilai semakin mendekati 1 berarti hubungan yang terjadi semakin kuat, sebaliknya apabila nilai semakin mendekati 0 maka hubungan yang terjadi semakin lemah. Hal ini berarti bahwa terjadi hubungan yang kuat antara keadilan organisasi terhadap kepuasan kerja. pengaruh keadilan organisasi dengan kepuasan kerja dapat dilihat dari R Square yaitu sebesar 0,487. Hal ini berarti bahwa keadilan organisasi berpengaruh terhadap kepuasan kerja sebesar 48,7\% sedangkan sisanya 51,3\% dipengaruhi oleh faktor-faktor lain yang tidak diteliti dalam model regresi. Harga $t$ hitung $(\beta=0.631, t=4,554$, nilai $p \leq 0,05)$. Maka dapat diambil kesimpulan bahwa terdapat pengaruh positif Keadilan organisasi berpengaruh secara positif dan signifikan terhadap kepuasan kerja sehingga hipotesis pertama diterima.

\section{Pengujian Hipotesis 3}

Hipotesis yang ketiga dalam penelitian ini adalah terdapat pengaruh positif keadilan organisasi terhadap komitmen organisasi dengan kepuasan kerja sebagai variabel mediasi. Hasil yang diperoleh dari analisis regresi dapat dilihat tabel 4.6 sebagai berikut:

Tabel 4.6. Ringkasan Uji Hipotesis 3: Pengaruh Keadilan organisasi terhadap komitmen organisasi kepuasan kerja variabel mediasi

\begin{tabular}{|c|c|c|c|c|c|c|}
\hline \multirow[b]{2}{*}{ Variabel } & \multicolumn{2}{|c|}{$\begin{array}{c}\text { Unstandardized } \\
\text { Coefficient }\end{array}$} & \multirow[t]{2}{*}{ T hitung } & \multirow[b]{2}{*}{ Sig. } & \multirow[b]{2}{*}{$\mathrm{R}$} & \multirow[b]{2}{*}{$\begin{array}{l}\mathrm{R} \\
\text { Square }\end{array}$} \\
\hline & $B$ & $\begin{array}{l}\text { Std. } \\
\text { Error }\end{array}$ & & & & \\
\hline Konstan & 29,623 & 5,749 & 5,153 & 0,000 & & \\
\hline $\begin{array}{l}\text { Keadilan } \\
\text { organisasi }\end{array}$ & 0,030 & 0,110 & 0,273 & 0,000 & 0,543 & 0,295 \\
\hline Kepuasan kerja & 0,525 & 0,122 & 4,318 & 0,786 & 0,543 & 0,295 \\
\hline
\end{tabular}

Dependent Variable: Komitmen Organisasi (KK)

Sumber: data primer diolah, 2017. 


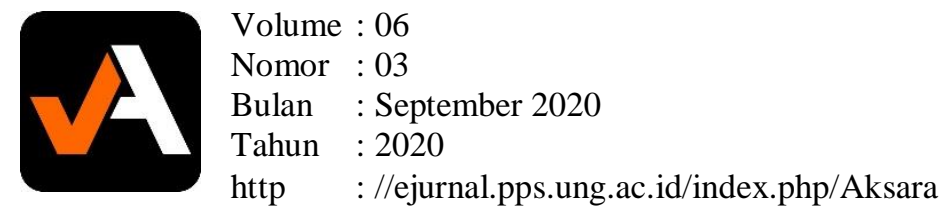

Berdasarkan Tabel 4.6, maka dapat dilakukan perhitungan variabel mediasi sebagai berikut:

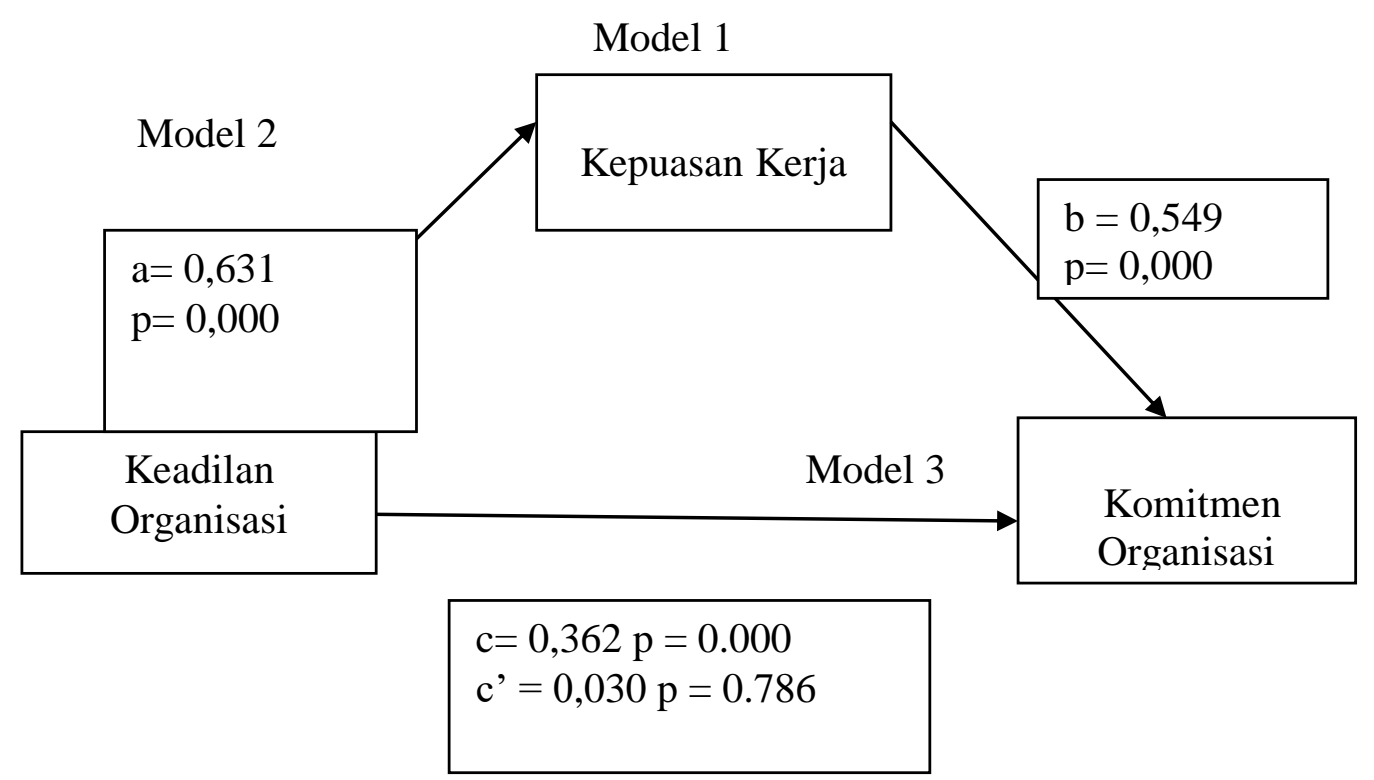

Hasil Path Analysis

Diagram jalur di atas menunjukkan anak panah dari model 1 ke kepuasan kerja yang menunjukan jumlah variance variabel kepuasan kerja yang tidak dijelaskan oleh keadilan organisasi. Kemudian model kedua menunjukkan komitmen organisasi menunjukkan variance komitmen organisasi yang tidak dapat dijelaskan oleh variabel keadilan organisasi dan kepuasan kerja.

Setelah melihat persyaratan untuk menentukan adanya pengaruh mediasi secara statistik, maka untuk mengetahui besarnya pengaruh langsung, tidak langsung dan total dari masing-masing variabel, diperlukan perhitungan dari nilai koefisien beta pada standardizid coefficient yaitu sebagai berikut:
a. Pengaruh langsung (KO ke KOM)
$=0,362$
b. Pengaruh tidak langsung (KO ke KOM mlalui KK)
$=0,346$
Pengaruh total
$=\overline{0,708}$

Pengaruh tidak langsung 0,346 diperoleh dari perhitungan 0,361 dikalikan 0,549. Untuk mengetahui hipotesis berpengaruh positif dan signifikan, maka dapat dilihat dari perhitungan menggunakan Sobel Test sebagai berikut:

$\mathrm{Sab}=\sqrt{b^{2}+s a^{2}+a^{2} s b^{2}+s a^{2} s b^{2}}$

Keterangan :

$\mathrm{ab}=$ Koefisien inderect effect yang diperoleh dari perkalian antara direct effect $\mathrm{a}$ dan $\mathrm{b}$

$b^{2}=$ Koefisien direct effect mediasi (X1) terhadap Y

$s a^{2}=$ Standard error dari koefisien a

$a^{2}=$ Koefisien direct effect independen (X) terhadap (Y)

$s b^{2}=$ Standard error dari koefisien $b$ 
$\mathrm{Sab}=\sqrt{0,549^{2}+0,066^{2}+(0,631)^{2}(0,087)^{2}+(0,066)^{2}(0,087)^{2}}$

$\mathrm{Sab}=\sqrt{0,301401+0,004356+0,398161+0,007569+0,004356+0,00756}$

$\mathrm{Sab}=\sqrt{0,001313+0,00301368+3,29706}$

$\mathrm{Sab}=\sqrt{0,00436}=0,066027$

$\mathrm{t}=\frac{\mathrm{ab}}{\mathrm{Sab}}$

$\mathrm{t}=\frac{0,631 \times 0,569}{0,0660}=5,449$

Oleh karena itu nilai t hitung 5,449 lebih besar dari t tabel dengan tingkat signifikansi 0,05 yaitu sebesar 1,672 , dan memiliki koefisien mediasi 0,345 signifikan yang berarti ada pengaruh mediasi. Dari hasil perhitungan t tersebut, maka dapat diambil kesimpulan bahwa pengaruh mediasi pada penelitian ini positif dan signifikan. Variabel dalam pengaruh mediasi dalam penelitian ini adalah kepuasan kerja. Dapat disimpulkan bahwa terdapat pengaruh positif keadilan organisasi terhadap komitmen organisasi dengan kepuasan kerja sebagai variabel mediasi. Hal tersebut berarti hipotesis ketiga dapat diterima.

Tabel 4.10 Rangkuman Hasil Uji Hipotesis

\begin{tabular}{|l|l|}
\hline Hipotesis & Keterangan \\
\hline $\begin{array}{l}\text { Hipotesis 1 } \\
\text { Keadilan organisasi berpengaruh } \\
\text { positif dan signifikan terhadap } \\
\text { komitmen organisasi }\end{array}$ & Diterima, signifikan positif \\
\hline $\begin{array}{l}\text { Hipotesis 2 kerja berpengaruh positif } \\
\text { Kepuasan kerja } \\
\text { dan signifikan terhadap komitmen } \\
\text { organisasi }\end{array}$ & Diterima, signifikan positif \\
\hline $\begin{array}{l}\text { Hipotesis 3 kepuasan kerja memediasi antara } \\
\text { keadilan organisasi terhadap } \\
\text { komitmen organisasi }\end{array}$ & Diterima, mediasi sempurna \\
\hline
\end{tabular}

Sumber: data diolah, 2017

\section{Keadilan Organisasi Berpengaruh Positif terhadap Komitmen} Organisasi

Berdasarkan hasil uji statistik dapat diketahui bahwa untuk Hipotesi pertama membuktikan bahwa keadilan organisasi berpengaruh positif dan signifikan terhadap komitmen organisasi. Artinya keadilan organisasi berpengaruh langsung dan signifikan terhadap komitmen organisasi. Hasil analisis menunjukan angka yang 


\begin{tabular}{|c|c|c|}
\hline \multirow[b]{5}{*}{ 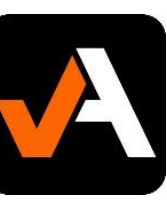 } & \multirow{2}{*}{\multicolumn{2}{|c|}{ Volume : 06}} \\
\hline & & \\
\hline & Nomor & $: 03$ \\
\hline & Bulan & : September 2020 \\
\hline & $\begin{array}{l}\text { Tahun } \\
\text { http }\end{array}$ & $\begin{array}{l}\text { : } 2020 \\
\text { : //ejurnal.pps.ung. }\end{array}$ \\
\hline
\end{tabular}

positif pada koefisien beta. Hal ini, menunjukan hubungan yang positif antara keadilan organisasi dengan komitmen organisasi. Hasil penelitian yang sama dengan penelitian sebelumnya yang dilakukan oleh Fulford (2005) dan Leen dan Wei (2015) menemukan bahwa faktor yang dapat mempengaruhi komitmen organisasi ditempat kerja adalah adanya keadilan organisasi. Secara garis besar para pekerja atau karyawan. Secara garis besar para pekerja atau karyawan kan mengevaluasi keadilan dalam tiga klasifikasi yaitu, keadilan interaksional keadilan distibusi dan keadilan prosedural. Dengan demikian penelitian tersebut dapat diterima dan sesuai dengan yang dilakukan oleh Nili, Hendijani dan Shekarchizadeh (2012), bahwa penelitian terhadap PT. Borneo Melintang Buana menghasilkan adanya pengaruh positif dan signifikan antara keadilan organisasi terhadap komitmen organisasi.

Penerapan aturan dan instruksi bagi karyawan di perusahaan keadilan organisasi diberlakukan bagi semua karyawan, seperti adanya standarisasi pemberian gaji, perlakuan yang sama pemilik kepada semua karyawan,

Hal tersebut juga dikonfirmasi oleh beberapa karyawan, yang menyatakan hal yang sama. Adanya perlakuan yang adil pada setiap karyawan dianggap karyawan dapat menciptakan situasi kerja yang baik, sehingga karyawan merasa betah bekerja di perusahaan. Jawad et al., (2012) mengatakan bahwa dengan adanya keadilan di dalam organisasi, maka karyawan akan merasa nyaman saat bekerja di perusahaan dan bekerja dengan senang hati. Hal ini membuat karyawan mempunyai rasa memiliki, yang mempunyai hubungan erat dengan komitmen, seperti kebanggaan terhadap perusahaan dan keinginan bertahan dalam perusahaan (Nurmadita dan warsidah 2015). Teori yang dikemukakan oleh Teori yang dikemukakan oleh Gibson, et al. (2012) juga mendukung hasil penelitian, karena beberapa dampak yang diberikan dari adanya keadilan organisasi adalah meningkatnya komitmen terhadap organisasi, meningkatnya kesetiaan karyawan terhadap organisasi, dan karyawan akan mempercayai supervisornya.

\section{Keadilan Organisasi Berpengaruh Positif terhadap Kepuasan Kerja}

Pengaruh hipotesis kedua menunjukkan adanya pengaruh positif antara keadilan organisasi dengan kepuasan kerja. Temuan yang dihasilkan penelitian ini semakin menguatkan kesimpulan penelitian-penelitian terdahulu tentang kuatnya dampak keadilan organisasi terhadap kepuasan kerja. Murphy et al., (2003) mencatat bahwa sejauh mana seseorang mempersepsikan keadilan organisasi, berkaitan dengan hasilhasil positif seperti kepuasan kerja dan perilaku karyawan. Demikian pula Chan (2000), yang menyimpulkan bahwa ketidakadilan dalam proses pengambilan keputusan dihubungkan dengan berbagai konsekuensi negatif seperti kinerja yang lebih rendah, keinginan berpindah yang lebih tinggi, pencurian yang lebih banyak, dan rendahnya komitmen organisasional. Jika dilihat kembali pada penjelasan teoritis yang ada, misalnya dari perspektif equity theory, dimana seseorang akan berusaha untuk memelihara agar rasio hasil mereka sendiri (imbalan) terhadap input mereka sendiri (kontribusi) tetap sama dengan rasio hasil/input orang lain tempat mereka memperbandingkan diri mereka. Orang-orang lain yang dijadikan basis perbandingan dapat merupakan orang lain dalam sebuah kelompok kerja, karyawan lain dalam sebuah perusahaan, seorang individu dalam bidang yang sama, atau bahkan seseorang yang hidup pada waktu yang berbeda atau terdahulu (Greenberg dan Baron, 2000). Jika individu-individu dalam organisasi mempersepsikan adanya 


Volume : 06
Nomor $: 03$
Bulan $\quad:$ September 2020
Tahun $: 2020$
http

ketidakadilan dalam kompensasi, maka mereka akan lebih cenderung menunjukkan sikap kerja yang lebih rendah. Dengan demikian, jika karyawan mempersepsikan bahwa mereka diperlakukan secara adil oleh perusahaan, maka mereka akan cenderung untuk memberikan timbal balik dengan menunjukkan sikap positif terhadap pekerjaan mereka, sikap positif terhadap perusahaan mereka.

\section{Kepuasan Kerja Memediasi Pengaruh Keadilan Organisasi terhadap} Komitmen Organisasi

Pengujian hipotesis ketiga bahwa kepuasan kerja memediasi pengaruh antara keadilan organisasi terhadap komitmen organisasi. Berdasarkan hasil regresi (tabel 4,10), setelah kepuasan kerja dimasukan ke dalam regresi untuk memprediksi keadilan organisasi terhadap komitmen organisasi menurun tetapi masih signifikan. Hasil tersebut menunjukkan bahwa kepuasan kerja memediasi secara parsial antara pengaruh keadilan organisasi terhadap komitmen organisasi. Hal tersebut berarti pada penelitian yang dilakukan memiliki pengaruh langsung yang sangat kuat. Apabila setelah memasukkan variabel kepuasan kerja pengaruh variabel $\mathrm{X}$ terhadap Y yang tadinya signifikan (sebelum memasukkan variabel kepuasan kerja) menjadi tetap signifikan setelah memasukkan variabel kepuasan kerja dalam model persamaan regresi tetapi mengalami penurunan koefisien regresi, maka kepuasan kerja dikatakan sebagai variabel mediasi sebagian (partial mediation). Keadilan organisassi berpengaruh Positif terhadap komitmen organisaasi melalui kepuasan kerja. Hasil penelitian ini sama dengan penelitian sebelumnya yang dilakukan oleh Crow et al., (2012) dan Niazi dan Ali (2014). Para peneliti sebelumnya menemukan bahwa adanya pengaruh antara keadilan organisasi terhadap komitmen organisasi, dipengaruhi faktor lain yaitu kepuasan kerja. adanya peran mediasi tersebut karena karyawan yang mendapatkan keadilan dapat mempengaruhi perilaku karayawan ditempat kerja. Selain itu, keadilan organisasi juga membentuk kepuasan kerja dalam diri karyawan sebelum mempengaruhi komitmen organisasi. Hasil yang diperoleh bahwa kepuasan kerja memediasi secara parsial pengaruh antara keadilan organisasi terhadap komitmen organisasi. Hasil ini menunjukkan bahwa kepuasan kerja tidak secara kuat mempengaruhi keadilan organisasi terhadap komitmen organisasi. Dengan kepuasan kerja memediasi secara parsial, mengindikasikan bahwa terdapat faktor lain yang dapat berperan sebagai mediasi diantara pengaruh keadilan organisasi terhadap komitmen organisasi. Meskipun ada faktor lain selain kepuasan kerja yang memediasi di antara pengaruh keadilan organisasi terhadap kepuasan kerja, namun perlu bagi perusahaan untuk tetap meningkatkan kepuasan kerja dalam diri karyawan karena merupakan penunjang lahirnya komitmen organisasi

\section{SIMPULAN}

Peneliti merumuskan simpulan berdasarkan hasil pengolahan dan analisis data untuk menjawab pertanyaan penelitian yang telah diajukan sebelumnya. Adapun simpulan yang dapat ditarik dalam penelitian ini, yaitu:

1. Keadilan organisasi berpengaruh positif dan signifikan terhadap komitmen organisasi. Perusahaan yang menerapkan imbalan dan mengikuti proses pembayaran adil dan memperlakukan karyawan dengan martabat dapat menunjang komitmen organisasi. Hasil penelitian PT. Borneo Melintang 
Buana menegaskan bahwa keadilan organisasi berpengaruh dan signifikan untuk menghasilakan komitmen organisasi.

2. Keadilan organisasi mempunyai pengaruh positif dan signifikan pada kepuasan yang ditunjukkan karyawan PT. Borneo Melintang Buana artinya semakin tinggi keadilan organisasi yang mereka rasakan, akan meningkatkan kepuasan mereka dalam berkerja pada PT. Borneo Melintang Buana.

3. Kepuasan kerja memediasi pengaruh keadilan organisasi terhadap komitmen organisasi. Adanya keadilan organisasi tidak hanya berpengaruh secara langsung terhadap komitmen organisasi, tetapi melalui kepuasan kerja yang juga memiliki peran untuk membentuk pribadi karyawan menjadi berkomitmen di tempat kerja. Hasil penelitian terhadap PT.Borneo Melintang Buana menunjukkan bahwa kepuasan kerja memediasi pengaruh antara keadilan organisasi terhadap komitmen organisasi

\section{DAFTAR PUSTAKA}

Colquitt, Jason A. (2001). "On The Dimensionality of Organizational Justice: A Construct Validation of a Measure". Journal of Applied Psychology, 86(3), pp: 386-400

Crow, Matthew S., Lee, Chang-Bae., Joo, Jae-Jin. (2012). Organizational Justice and Organizational Commitment Among Police Officers: An Investigation of Job Satisfaction as a mediator. Policing: An International Journal of Police Strategies and Management, 352, 402-423.

Cheng, S.Y.(2014). The Mediating Role of Organizational Justice on the Relationship between Administrative Performance Appraisal Practices and Organizational Commitment. The Internasional Journal Of Human Resouce Management, 25:8, 1131-1148.

Fulford (2005). That's Not Fair!: The Test of a Model of Organizational Justice, Job Satisfaction, and Organizational Commitment Among Hotel Employees. Journal of Human Resources in Hospitality \& Tourism, 4(1).

Greenberg, J. (1987). A Taxonomy Of Organizational Justice Theories. Academy of Management Review, 12, 9-22.

Gibson, J.L., Ivanevich, J.M., Donnelly, J.H., and Konopaske, R. (2009). Organizations: Behavior, Structure, Processes. 11thedition. New York: McGraw- Hill Irwin

Ivancevich John. M., Konopaske, R., Matteson,M.T (2006). Perilaku dan Manajemen Organisasi, Jakarta: Erlangga

Jiang, Z.(2015). The relationship between justice and commitment: the moderation of trust. Journal of Business Administration. Vol. 7 No. 1,

Karim, F dan Omar Rehman, (2012). Impact of Job Satisfaction, Perceived Organizational Justice and Employee Empowerment on Organizational Commitment in Semi-Government Organizations of Pakistan”. Journal of Business Studies Quarterly, 3, No. 4, 21521034.

Karim, Jahanvash. 2011. "Emotional intelligence, leader-member exchange, organizational justice, and outcome variables: a conceptual model". International Journal of Leadership Studies Vol 6:3

Kim, W.G. \& Brymer, R. A. (2011). The Effects Of Ethical Leadership On Manager Job Satisfaction, Commitment, Behavioral outcomes, \& Firm Performance. InternationalJournal of Hospitality Management, 30, 1020-1026.

Kinicki dan Fugate. (2013). Organizational Behavior Fifth Edition. McGraw-Hill Education.New York 


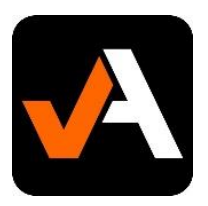

Volume : 06

Nomor : 03

Bulan : September 2020

Tahun : 2020

http : //ejurnal.pps.ung.ac.id/index.php/Aksara

Kristanto, H. (2015). Keadilan Organisasional, Komitmen Organisasional, Dan Kinerja Karyawan. JMK. VOL. 17, NO. 1, 86-98

Leen, J dan Wei, (2015). The Moderating Effect Of Leadership on Perceived Organizational Justice and affective Commitment: a Study in China. The Internasional Journal Of Human Resouce Management. ISSN 0958-5192

Niazi, Amna and Ali, Muhammad 2014. The Relationship Between Organizational Justice and Organizational Commitment and The Mediating Role of Job Satisfaction on Organizational Behavior. International Journal of Management Sciences and Business Research. ISSN (2226-8235).Vol 3.Issue 2.

Nili,M.,Hendijani,M,. dan Shekarchizadeh.( 2012). Measuring The Impact Of Perceived Justice On Organizational Commitment In Isfahan Municipality. Interdisciplinary Journal Of Contemporary Research In Business, 4, 5.

Nurmaladita dan Warsindah.L (2015). Pengaruh Keadilan Organisasi Terhadap Komitmen Organisasi Melalui Kepuasan Kerja pada Karyawan bank BNI Kantor Cabang Utama Margonda, Depok, Jawab Barat. Seminar Nasional Cendikiawan, 2460-8696

Mowday, R.T, Porter, L.W dan Steers R.M. (1982). Employee Organization Lingkages: The Psychology of Commitment, Absenteeism and Turnover, Academic Press Inc, London

Rahmi. B. M.( 2014). Pengaruh Kepemimpinan Transformasional Terhadap Organizational Citizenship Behavior Dan Komitmen Organisasional Dengan Mediasi Kepuasan Kerja (Studi pada Guru Tetap SMA Negeri di Kabupaten Lombok Timur). Jurnal manajemen Udayana. Vol 3, 2

Rivai.V,.Mulyadi,D. (2012). Kepemimpinan dan Perilaku Organisasi, Jakarta: Kharisma Putra Utama Offset

Robbins, S.P., \& Judge, T.A. (2008). Perilaku Organisasi, Edisi 2. Penerbit Salemba Empat.

Sancoko, C. A dan Panggabean, S.M. (2015). Pengaruh Keadilan Organisasi Terhadap Komitmen Organisasional Dengan Kepuasan Kerja Sebagai Variabel Intervening Di Sekolah Santa Ursula Bsd. Jurnal MIX, Vol V, No. 1

Sariningtyas, E.R. (2016). Analisis Karakteristik Individu Dan Motivasi Intrinsik Terhadap Komitmen Organisasi Dengan Kepuasan Kerja Sebagai Variabel Intervening (Studi Pada Pdam Tirta Mulia Kabupaten Pemalang). Jurnal Ilmiah UNTAG Semaran. 2302-2752, Vol. 5 No. 1

Sušanj dan Jakopec (2012). Fairness Perceptions and Job Satisfaction as Mediators of the Relationship between Leadership Style and Organizational Commitment. Department of Psychology, Faculty of Humanities and Social Sciences, 3, 509-526

Spagnoli.P dan Caetano.A (2012). Personality And Organisational Commitment: The Mediating Role Of Job Satisfaction During Socialisation. Career Development International, $17: 3$ pp. $255-275$

Price, J. L, dan Mueller, C. W.(1986). Handbook of Oganizational measurements, Marshfield, MAPitman.

Priyatno,D. (2010). Teknik Mudah dan Cepat Melakukan Analisis Data Penelitian dengan SPSS. Penerbit Gava Media 